\title{
OCCUPATIONAL ASTHMA DUE TO MANGANESE EXPOSURE: A CASE REPORT
}

\section{TOMASZ WITTCZAK, WOJCIECH DUDEK, ANNA KRAKOWIAK, JOLANTA WALUSIAK, and CEZARY PALCZYŃSKI}

Department of Occupational Diseases, Centre of Occupational and Environmental Allergy

Nofer Institute of Occupational Medicine

Łódź, Poland

\begin{abstract}
Manganese belongs to a group of agents called "transitional metals" that are known to induce occupational asthma. However, well-documented cases of manganese-induced asthma have been lacking thus far. We have discussed a case of a 42-year-old non-smoking welder with work-related dyspnea. A number of clinical procedures were performed including clinical examination, routine laboratory tests, total serum IgE, skin prick tests to common aeroallergens and manganese nitrate, resting spirometry test, histamine challenge, and a single-blind, placebo-controlled specific inhalation challenge with $0.1 \%$ manganese chloride solution. Clinical findings and laboratory test results remained normal but a significant bronchial hyperreactivity was found. During the specific inhalation challenge, dyspnea and a significant decrease in forced expiratory volume (FEV1) were observed. An increased proportion of eosinophils and basophils in induced sputum could also be noted at 4 and $24 \mathrm{~h}$ after the challenge. The argument for recognizing the condition as occupational asthma was a positive clinical response to the specific challenge test as well as the morphological changes found in induced sputum. To our knowledge, this is the first well-documented case of manganese-induced occupational asthma
\end{abstract}

Key words:

Manganese, Occupational asthma, Bronchial challenge

\section{INTRODUCTION}

Manganese is a silver-white, extremely hard metal. It is used in the metallurgic industry to improve the strength, toughness and hardness of different alloys, and their rolling and forging qualities. This metal is also used in the manufacture of arc welding electrodes; in the ceramic industry to colorize glass and ceramic products, in the dry-battery industry, and also in the manufacture of dyes, paints, fungicides, and pharmaceuticals. Workers are rarely exposed to pure manganese, more often to its salts.

Excess exposure to manganese is toxic. There are two possible pathways of manganese toxicity. The first one is neurotoxicity, which is responsible for the development of Parkinson's-like disease. The second one, related to the respiratory system, is the manganese-induced pneumonia [1]. Longlasting exposure can also be associated with pulmonary disorders such as interstitial lung fibrosis [2]. Up to now, the only case of manganese-induced occupational asthma was that described by Saakadze et al. in 1977 [3].

\section{METHODS}

We report on a case of a 42-year-old never-smoking welder admitted to the Department of Occupational Diseases with a suspected occupational asthma. He had been working for 20 years at the train factory. His job tasks included welding for at least four hours per day. The patient was exposed to industrial aerosols containing manganese, crystalline silica, nitric oxide, carbon oxide, and iron oxide. After 10 years of working as a welder, he developed recurrent non-productive cough. Four years since then, he experienced the first episode of dyspnea. On admission, he had a history of recurrent dyspnea with wheezing that

Received: September 5, 2007. Accepted: November 19, 2007.

Address reprint to T. Wittczak, MD, Department of Occupational Diseases, Nofer Institute of Occupational Medicine, św. Teresy 8, 91-348 Łódź, Poland (e-mail: tomekwit@imp.lodz.pl). 
usually occurred after 30-60 minutes of welding, over the period of the last six years. As reported by his GP, a higher than $20 \%$ variability in PEFR could be observed on the days the patient had been exposed, compared to the days he stayed away from work.

We performed a clinical examination, routine laboratory testing, total serum IgE (Uni-CAP system Pharmacia Diagnostics, Uppsala, Sweden), skin prick tests (SPTs) to common aeroallergens (dust mites, tree and grass pollens, molds, feathers) (Allergopharma, Germany) and to $0.01 \%, 0.1 \%$ and $1 \%$ solutions of manganese nitrate, as well as resting spirometry and histamine challenge test (Mijnhardt spirometer, The Netherlands).

After that, the patient was subjected to a single-blind, placebo-controlled specific inhalation challenge with $0.1 \%$ manganese chloride solution. The test with placebo (1\% potassium chloride solution) was performed two days before the specific challenge. Both the allergen and placebo were administered by a nebulizer for 5 minutes.

Cellular composition of induced sputum was analyzed. Induced sputum samples were collected $10 \mathrm{~min}$, before the provocation and $4 \mathrm{~h}$ and $24 \mathrm{~h}$ afterwards. The processing of induced sputum has been described elsewhere [4].

\section{RESULTS}

The clinical and laboratory findings (including chest x-ray) were normal. Total serum IgE was low $(31.36 \mathrm{KU} / \mathrm{l})$. SPTs to common aeroallergens and to $0.01 \%, 0.1 \%$ and $1 \%$ solutions of manganese nitrate were negative. Resting spirometry varied from normal to a mild obstruction: FEV1 from 3.551 ( $85 \%$ predictive values) to 2.541 (57\%), FVC from 4.341 (80\%) to 5.981 (115\%). Histamine challenge revealed significant bronchial hyperreactivity $\left(\mathrm{PC}_{20}=0.5 \mathrm{mg} / \mathrm{ml}\right)$.

On the day of specific challenge, resting spirometry was as follows: FEV1 2.761 (66\%), FVC 5.311 (104\%). Five minutes after manganese chloride inhalation was over, dyspnea occurred, and a $45 \%$ decrease in forced expiratory volume (FEV1), dropping down to $55 \%$ at $1 \mathrm{~h}$, and slightly rising to $35 \%$ at $24 \mathrm{~h}$ was observed (Fig. 1). Also an increase in the proportion of eosinophils and basophils

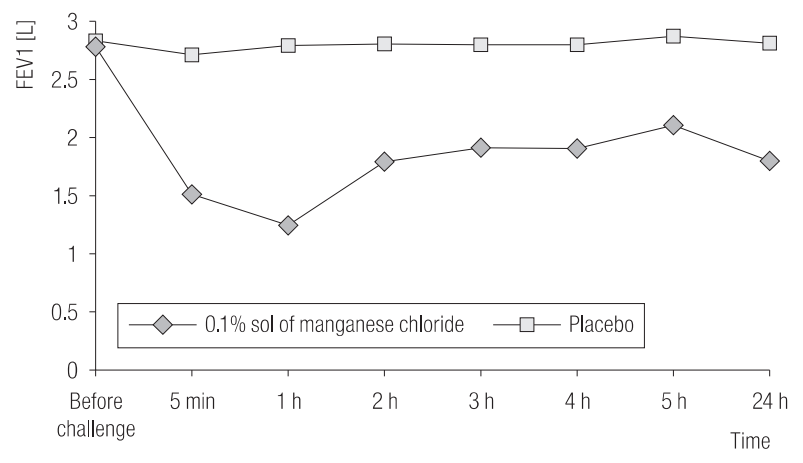

Fig 1. Changes in FEV1 values after specific challenge with manganese chloride and placebo.

in induced sputum could be noted after manganese chloride exposure at 4 and $24 \mathrm{~h}$ after the challenge (Table 1). Placebo test did not produce any clinical, spirometric, or significant cell proportion changes.

The controls were two volunteers: a 39-year-old male with atopic asthma due to Dermatophagoides pteronyssinus and a 34-year-old healthy male. Both of them were subjected to specific inhalation challenge with $0.1 \%$ manganese chloride solution under similar conditions. None of the examined subjects developed clinical symptoms after

Table 1. Changes in the proportion of eosinophils and basophils in induced sputum after specific challenge with $0.1 \%$ manganese chloride solution compared to the findings for placebo challenge, and manganese chloride challenge in healthy and asthmatic controls

\begin{tabular}{|c|c|c|c|}
\hline Parameter/subject & $\begin{array}{l}\text { Before } \\
\text { challenge }\end{array}$ & $\begin{array}{l}4 \mathrm{~h} \text { after } \\
\text { challenge }\end{array}$ & $\begin{array}{l}24 \mathrm{~h} \text { after } \\
\text { challenge }\end{array}$ \\
\hline $\begin{array}{l}\text { Eosinophils/manganese } \\
\text { chloride challenge }\end{array}$ & $0 \%$ & $8 \%$ & $10 \%$ \\
\hline $\begin{array}{l}\text { Basophils/manganese chloride } \\
\text { challenge }\end{array}$ & $0 \%$ & $1 \%$ & $3 \%$ \\
\hline Eosinophils/placebo challenge & $0 \%$ & $1 \%$ & $2 \%$ \\
\hline Basophils/placebo challenge & $0 \%$ & $0 \%$ & $0 \%$ \\
\hline $\begin{array}{l}\text { Eosinophils/manganese } \\
\text { chloride challenge in } \\
\text { asthmatic control }\end{array}$ & $0 \%$ & $1 \%$ & $0 \%$ \\
\hline $\begin{array}{l}\text { Basophils/manganese chloride } \\
\text { challenge in asthmatic } \\
\text { control }\end{array}$ & $0 \%$ & $0 \%$ & $0 \%$ \\
\hline $\begin{array}{l}\text { Eosinophils/manganese chloride } \\
\text { challenge in healthy control }\end{array}$ & $0 \%$ & $0 \%$ & $0 \%$ \\
\hline $\begin{array}{l}\text { Basophils/manganese chloride } \\
\text { challenge in healthy control }\end{array}$ & $0 \%$ & $0 \%$ & $0 \%$ \\
\hline
\end{tabular}


the challenge. Moreover, no significant changes could be found in the number and proportion of eosinophils and basophils in induced sputum

\section{DISCUSSION}

Manganese belongs to a group of agents called the "transitional metals" which is located between groups IIA and III of the periodic table of elements. The other metals from this group: chromium, cobalt, and nickel are known to induce occupational asthma. Thus far, all the metals that cause asthma can be classified within the main transition metal series. Their propensity to induce specific immunological changes resulting in asthma after occupational exposure may be linked to their respective orbital structures. A similar chemical structure of manganese may thus determine its asthmogenic potential [5-7].

However, to our knowledge, the presently described condition is the first well-documented case of manganese-induced occupational asthma. The diagnosis was based on the clinical response to specific challenge and the accompanying changes in induced sputum. An in-depth analysis of the report by Saskaadze who described what seemed to have been a manganese-induced occupational asthma revealed some issues that may have produced a false conclusion from the study. Saskaadze et al. used a $20 \%$ solution of manganese chloride for the provocation test, which seems to be too hypertonic for the inhalation test. It is plausible that such a solution could produce the bronchial spasm because of its hypertonity rather than an allergic reaction. Moreover, no placebo control or inflammatory cell assessment was performed, which could confirm the allergic nature of the bronchoconstriction.

\section{REFERENCES}

1. Brooks MS. Pulmonary reactions to miscellaneous mineral dust, man-made mineral fibers and miscellaneous pneumoconiosis. In: Occupational respiratory diseases. Washington: National Institute of Occupational Safety and Health; 1986. p. 431-2.

2. Hobbesland A; Kjuus H; Thelle DS: Mortality from nonmalignant respiratory diseases among male workers in Norwegian ferroalloy plants. Scand J Work Environ Health 1997;23:342-50.

3. Saakadze VP; Vasilov BG. Occupational bronchial asthma from exposure to manganese. Gig Tr Prof Zabol 1977;6:19-23.

4. Krakowiak A, Krawczyk-Adamus P, Dudek W, Walusiak J, Pałczyński C. Changes in cellular and biochemical profiles of induced sputum after allergen-induced asthmatic response: Method for studying occupational allergic airway inflammation. Int J Occup Med Environ Health 2005;18:27-33.

5. Boojar MM, Goodarzi F. A longitudinal follow-up of pulmonary function and respiratory symptoms in workers exposed to manganese. J Occup Environ Med 2002;44:282-90.

6. Bernstein IL, Merget R Metals. In: Bernstein IL, Chan-Yeung M, Malo JL, Bernstein DI, editors. Asthma in the workplace. Third Edition. New York, London: Taylor \& Francis; 2006. p. 525-54.

7. Mapel D, Coultas D. Disorders due to minerals other than silica, coal and asbestos, and to metals. In: Hendrick DJ, Burge PS, Beckett WS, Churg A, editors. Occupational disorders of the lung. London: WB Saunders; 2002. p 163-90. 